\title{
Äännehistoriaa suomen kielen erilliskehityksen alkutaipaleilta
}

Johdanto

Suomen kielen erilliskehityksen voitaneen katsoa alkaneen noin vuoden 700 jKr. paikkeilla, jolloin pohjoiskantasuomi jakautui areaalisesti länsisuomeen, muinaiskarjalaan ja muinaisvepsään (Kallio 2014; 2019). Vaikka kielellinen eriytyminen alkoi vasta tästä, länsisuomen kehityskaudet voidaan silti jakaa seuraavasti: ${ }^{1}$

1. varhaissuomi noin 700-1200.

2. keskiajan suomi noin 1200-1540.

3. vanha kirjasuomi noin $1540-1820$.

4. varhaisnykysuomi noin $1820-1870$.

5. nykysuomi noin $1870-$.

Jaotteluni perustuu pääasiassa Osmo Ikolaan (1965), josta poiketen kannatan kuitenkin jo Heikki Ojansuun $(1916 ; 1926)$ lanseeraamaa jakoa varhaissuomeen ja keskiajan suomeen, ${ }^{2}$ sillä keskiajan suomi oli hyvin samanlainen siirtymäkausi esihistoriallisen varhaissuomen ja historiallisen vanhan kirjasuomen välillä kuin varhaisnykysuomi vanhan kirjasuomen ja nykysuomen välillä. Muutenkin tämän vuosituhannen puolella keskiajan suomesta on jälleen alettu puhua ääneen (Häkkinen 2001; Bentlin 2011; Blomqvist 2016).

1 Jo heti näin aluksi korostettakoon, että muinaiskarjalan yhteyteen kuuluvan itäsuomen kehityskaudet ovat kokonaan oma lukunsa (ks. erit. Leskinen 1964), enkä tule niihin tässä artikkelissani liiemmin puuttumaan, sillä olen kirjoittanut aiheesta laajemmin toisaalla (Kallio 2019).

2 Samaa jakoa on kannattanut myös Mikko Heikkilä (2016, 153-154), jonka ehdottama terminologia esisuomi noin 600-1232 ja varhaissuomi noin 1232-1540 - aiheuttaisi kuitenkin sekaannuksia, sillä esisuomi on jo vakiintunut esi-itämerensuomen synonyymiksi. Vuoden 1232 valitsemista käännekohdakseen hän ei perustele. 
Varhaissuomalainen kehityskausi supistuu näin ollen pyöreästi 500 vuoteen, mikä on silti pitkä aika lingvistisestä näkökulmasta. Esimerkiksi massiiviset muutokset muinaisenglannista nykyenglantiin tapahtuivat suunnilleen samassa ajassa. Suomi puolestaan on tunnetusti konservatiivinen kieli, jossa ei edes kantauralin ja nykysuomen välillä tapahtunut mitään vastaavaa. Yhtä kaikki on selvää, ettei varhaissuomi myöskään säilynyt puolta vuosituhatta muuttumattomana, koska sellainen uhmaisi jo lingvistisiä universaaleja.

Siinä missä varhaissuomesta ei ole kirjallisia muistomerkkejä, keskiajan suomesta on taltioitu jopa pari lausetta (Wulf 1982), jos kohta ylivoimainen enemmistö aineistosta tulee tuhansien paikan- ja henkilönnimien muodossa. Tätä aineistoa on myös älytty hyödyntää aivan vertailevan fennistiikan alkutaipaleilta lähtien (esim. Setälä 1890-1891), joskin useimmiten on lisäksi ymmärretty, että kyse oli yleensä muiden kuin natiivien suomenpuhujien käsin kirjoittamista nimistä, joissa kaikenlaiset kirjoitus- ja kopiointivirheet olivat täten pikemmin sääntö kuin poikkeus.

Koska morfologia ja syntaksi jäisivät auttamatta torsoiksi, keskityn kirjoituksessani varhaissuomen ja keskiajan suomen fonologiaan (vrt. Heikkilä 2016). Lähtökohtani on pohjoiskantasuomalainen foneemiparadigma (ks. taulukko 1), joka oli melkein identtinen myöhäiskantasuomalaisen kanssa (Kallio 2016, 40). Ainoa mahdollinen poikkeus oli ${ }^{*} \ddot{e}\left(=\right.$ SUT ${ }^{*} e$, IPA $\left.{ }^{*} \gamma\right)$, josta kehittyi kaikissa ympäristöissä ${ }^{*} e$ (Kallio 2014, 160-161). Toisaalta ${ }^{\star} c$ oli foneemina häviämässä, sillä se esiintyi enää vain geminaattana sekä yhtymässä * $c r$ (Kallio 2007, 241-242; 2012, 231).

Tarkkaavainen lukija saattaa huomata myös soinnittomien klusiilien ${ }^{\star} p,{ }^{\star} t,{ }^{*} k$ heikkoasteisiksi allofoneiksi merkitsemäni soinnilliset klusiilit ${ }^{*} b,{ }^{*} d,{ }^{*} g$ (pro soinnilliset spirantit $\left.{ }^{\star} \beta,{ }^{\star} \delta,{ }^{*} \gamma\right)$. Seuraan tässä E. N. Setälän alkuperäistä kantaa $(1890-1891)$, jota yli vuosisata myöhemmin asettuivat tukemaan Jorma Koivulehto ja Theo Vennemann (1996) edelleen huomionarvoisin yleislingvistisin perustein. Nyttemmin soinnillisia klusiileja ovat alkaneet kantasuomalaisissa rekonstruktioissaan käyttää muutkin (esim. Aikio 2014; Kallio 2016), vaikka niitä ei yleisesti hyväksyttyinä voikaan toistaiseksi pitää.

Taulukko 1. Pohjoiskantasuomen foneemit

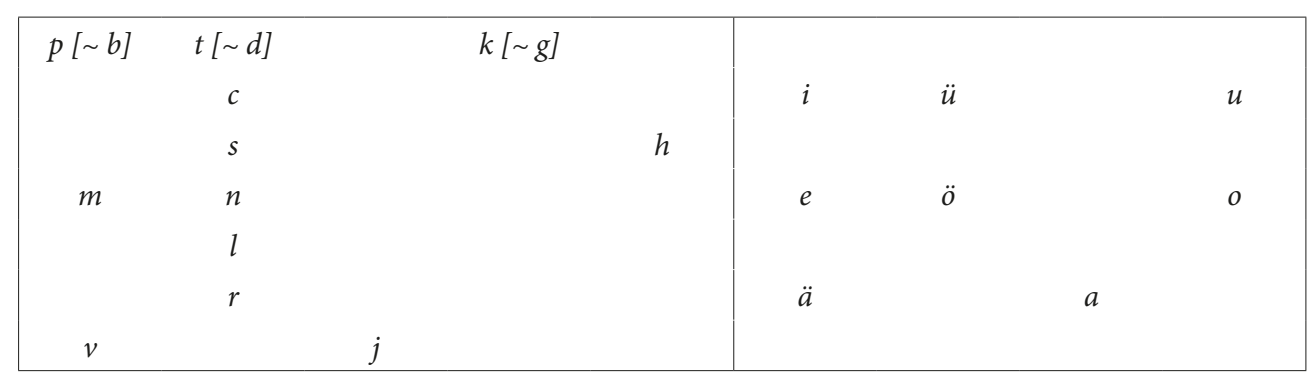




\section{Varhaissuomi}

Viime vuosikymmenellä Tiede-lehdessä udeltiin, ymmärtäisikö nykysuomalainen muinaissuomea, jolloin Tapani Lehtinen osin leikkimielisesti sepitti seuraavan mukaelman antaakseen "jonkinlaisen käsityksen siitä, miltä varhaissuomi saattoi kuulostaa noin tuhat vuotta sitten" (2005):

Alyussa Jumala loi taivahan ja maan. Ja maa oli autio ja tyhjä, ja pimeঠys oli syvyઈen päällä, ja Jumalan henki liikkui vetten päällä. Ja Jumala sanoi: ”Tul-

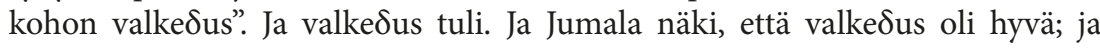

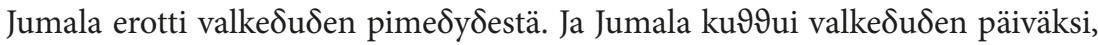

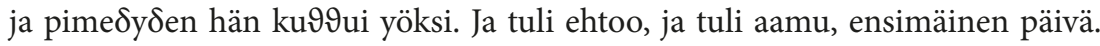
(1. Moos. 1: 1-5. $)^{3}$

Lehtinen tuskin itsekään uskoi varhaissuomen syntaksin säilyneen muuttumattomana vuoden 1933 raamatunkäännökseen saakka, vaan hän lienee tarkoituksella keskittynyt varhaissuomalaistamaan ainoastaan fonologian. Senkin suhteen hänen varhaissuomensa sisältää piirteitä, jotka monet muut ajoittaisivat vasta keskiajalle tai jopa vielä myöhemmiksi (vrt. Palomäki 1998). Siltikin otin hänen mukaelmansa tähän, koska sen lisäksi, ettei varhaissuomesta ole kirjallisia muistomerkkejä, siitä ei liiemmin ole ollut tällaisia rekonstruktioita, joista valaisevasti ilmenisivät sen tärkeimmät fonologiset innovaatiot (näistä tarkemmin Lehtinen 2007, 168-197):

1. ${ }^{*} b>{ }^{*} \beta,{ }^{*} d>{ }^{*} \delta,{ }^{*} g>{ }^{*} \gamma$ (vrt. alyussa, pime $\delta y s$ jne.). - Oletettavasti samassa yhteydessä tapahtui soinnillisen konsonantin edellä ${ }^{*} p>{ }^{*} \beta,{ }^{*} t>{ }^{*} \delta,{ }^{*} k>{ }^{*} \gamma$, vaikka tästä Lehtinen ei antanut esimerkkejä (kuten ei myöskään siitä, että ${ }^{\star} \beta$ lankesi ennen pitkää kaikkialla yhteen ${ }^{*} v$ :n kanssa).

2. ${ }^{*} c c>{ }^{*} 9 \vartheta$ (vrt. $\left.k u \vartheta 9 u i\right)$. - Houkuttelevaa olisi ajoittaa tämä ja edellinen innovaatio (eli soinnittoman ja soinnillisen spirantin synty) samanaikaiseksi, sillä $\vartheta 9$ ja $\delta$ väistyivät niin ikään rinta rinnan säilyen pisimpään pitkälti samoissa pitäjissä (Streng 1907; Virtaranta 1958). Samaan yhteyteen voisi sijoittaa lisäksi kehityksen ${ }^{*} c r>{ }^{*} \vartheta r>{ }^{*} h r$, josta ei tosin Lehtisellä ollut esimerkkejä, koska yhtymä esiintyi ylipäänsä vain muutamassa sanassa (esim. kehrä, ohra; Kallio 2012, 231).

3. ${ }^{\star}$ oo $>{ }^{\star} u o,{ }^{\star} \ddot{o} o ̈>{ }^{\star} \ddot{u} \ddot{o},{ }^{\star} e e>{ }^{\star}$ ie (vrt. yöksi). - Lehtinen kirjoitti ${ }^{\star} \ddot{u}: \mathrm{n}$ suomen ortografian mukaisesti ${ }^{*} y:$ llä.

4. ${ }^{*} \gamma>\varnothing$ painottoman tavun jäljessä (vrt. ehtoo). - Kyse oli ilmiselvästi edellisiä muutoksia myöhemmästä kehityksestä (vrt. * ehtayo > ehtoo pro †ehtuo; ${ }^{*}$ sate ${ }^{*}$ en $>$ sateen pro $\dagger$ satien). Siitä huolimatta Lehtinen oletti ${ }^{\star} \delta$ :n kadon samassa asemassa vielä myöhemmäksi, sillä hän jätti sen esimerkkisanoissaan paikoilleen (vrt. pime $y$ s jne.).

3 Alkuperäisessä artikkelissa oli harmittava fonttivirhe $v$ pro $\vartheta$, jonka olen tähän korjannut. 
Kirjallisten muistomerkkien puuttuessa on tietenkin mahdotonta tarkalleen tietää, kuinka autenttista Lehtisen varhaissuomi on. Jos unohdamme hänen syntaksinsa, itse suhtaudun skeptisimmin siihen tietoon, että nykysuomalainen asu ehtoo olisi sellaisenaan ollut olemassa jo vuosituhat sitten, sillä Länsipohjan murteen ehtavo 'ehtoollinen' (SMS s.v. ehtavo) palautuu yhteen ja samaan lähtöasuun *ehtayo. Sen sijaan kolme ensimmäistä esimerkkiä on yleisemminkin tunnustettu itämerensuomen länsisuomalaisen kantamurteen keskeisimmiksi fonologisiksi innovaatioiksi (esim. Salminen 1998, 403-404).

Fonologisten innovaatioiden absoluuttinen ajoittaminen on silti huomattavasti helpommin sanottu kuin tehty. Äärimmäisenä esimerkkinä mainittakoon ${ }^{*} c c>{ }^{\star} \vartheta \vartheta$, jonka Terho Itkonen (1981) ajoitti viimeistään vuoteen 700 siinä missä Ulla Palomäki (1998) aikaisintaan 1500-luvun lopulle. Itkosen ajoitus perustui olettamukseen, että muutos olisi saanut alkunsa tuolloisesta skandinaavista, jossa $p(=\operatorname{SUT} \vartheta$, IPA $\theta)$ esiintyi mutta josta $t$ s puuttui. Selitys on muuten kaikin puolin moitteeton, mutta ei vain ole pakottavaa tarvetta olettaa, että ${ }^{*} c c>{ }^{*} \vartheta \vartheta$ olisi ollut vierasta vaikutusta, sillä vastaavalle kehitykselle tunnetaan paralleeleja muualtakin (vrt. Kümmel 2007, 194-196). ${ }^{4}$

Palomäen ajoitus taas perustui oletukseen, että vanhan kirjasuomen $t z$ ja $d z$ olisi sittenkin tulkittava affrikaatoiksi (vrt. jo Setälä 1890-1891, 172-179). Kieltämättä kyseessä onkin järkeenkäyvempi vaihtoehto kuin se, että Mikael Agricolaa vanhempi keskiaikainen käsikirjoitustraditio olisi johtanut spiranttien merkitsemiseen $t z$ :lla tai $d z$ :lla (Rapola 1966, 186). Ainakaan parhaalla asiantuntijalla eli Agricolalla itsellään ei näyttänyt olleen tällaisesta traditiosta tietoa, kun hän kirjoitti pääteoksensa Se Wsi Testamenti esipuheessa (1548): Nyt ette temen Maan kieli oli ennen neite aicoija / iuri wähe / ia lehes ei miteken kirioisa eli pockstauisa prucattu taicka harioitettu. ${ }^{5}$

Kaikesta huolimatta myöskään Palomäen teesi vanhan kirjasuomen affrikaatoista ei kestä kriittistä tarkastelua (Rintala 1999). Selitys spiranttien merkitsemiseen $t z$ :lla ja $d z$ :lla löytyneekin ruotsista, jossa tunnetusti tapahtui assimilaatio $t s>s s$ (vrt. mru. $r y(t / d) z>$

4 Itkosen selitys kuului aikaan, jolloin moni fenn(ougr)isti Lauri Postia seuraten oletti innolla äänteenmuutoksia vieraan vaikutuksen aiheuttamiksi mekaanisiksi äännesubstituutioiksi. Äärimmilleen tällaisen kontaktiteoreettisen ajattelutavan vei tunnetusti Kalevi Wiik, jonka jälkeen syntyikin terve vastareaktio kaikkia samanhenkisiä selityksiä kohtaan (Kallio 2000; Saarikivi 2000). Kuten Jani-Matti Tirkkonen $(2012,93)$ on terävästi analysoinut, kontaktiteorian lisäksi Wiik vei jatkuvuusteorian liiallisuuksiin sillä seurauksella, että uusi sukupolvi päätyi jälleen vastakkaiseen ääripäähän (Aikio-Aikio 2001; Kallio 2006). Samoin Wiikin ajatukset uralilaisesta substraatista ei-uralilaisissa kielissä johtivat ajatukseen ei-uralilaisesta substraatista uralilaisissa kielissä (Aikio 2004; Saarikivi 2004). Wiikin ansioita tieteellisenä inspiroijana ei siis voi vähätellä, vaikka hänen kanssaan ei samaa mieltä olisi ollutkaan.

5 Suomenkielistä keskiaikaista käsikirjoitustraditiota on sinänsä perusteltu vakuuttavilla todisteilla (Koivusalo 1984; Nikkilä 1994, 13-16), mutta valitettavasti vakuuttavin mahdollinen todiste, suomenkieliset keskiaikaiset käsikirjoitukset, on jatkuvasti puuttunut. Tuhansien meidän päiviimme säilyneiden Suomea koskevien keskiaikaisten asiakirjojen joukossa ei ole yhtä ainutta suomen kielellä kirjoitettua. Toisaalta vuoden 1540 molemmin puolin alkoi useammaltakin taholta tulvia nykyaikaan asti säilyneitä suomenkielisiä tekstejä (Pirinen 1988; Nikkilä 1994, 17-37). Vaikka keskiajan suomen käsikirjoituksista onkin epäsuoraa evidenssiä, niiden määrän on täytynyt olla niin vaatimaton, ettei ortografisia konventioita päässyt syntymään - varsinkaan kun edes vanhaan kirjasuomeen ei sellaisia juuri syntynyt ennen vuoden 1642 raamatunkäännöstä (Rapola 1933, 66-69; 1962, 44-53). 
nru. ryss 'venäläinen'; Riad 2005, 1114). Vaikka ilmiöstä löytyy positiivista evidenssiä jo keskiajalta, ortografia säilyi silti merkillisen horjuvana pitkälle uudelle ajalle. Assimilaatiolla saattoi siis hyvin olla väliaste $[\theta s]$, jota grafeemin $p$ jo kadottua kuvattiin vanhasta muistista $t z$ :lla ja $d z$ :lla, mutta myös spiranttiääntämystä paremmin kuvaavat $s, s s, s z$, $d s$, $d s s, d s z, d z s, d z s s$ jne. olivat mahdollisia (ks. esim. SAOB s.v. ryss sbst. ${ }_{3}$ ).

Vanhan kirjasuomen $t z$ ja $d z$ juontuisivat siis siitä, että myös ruotsissa niillä olisi tuolloin ainakin murteittain merkitty jotain hyvin samankuuloista. Huomattakoon, että Agricolan suosiman $t z$ :n ja vuoden 1642 raamatunkäännöksen suosiman $d z$ :n rinnalla tapaamme kirjallisuudesta ja asiakirjoista pitkälti samoja yhtä kirjavia kirjoitusasuja kuin ruotsistakin (Palomäki 1998, 239-295). Vertailun vuoksi vaikka saksan Agricolan aikainen ortografia ei muutoin ollut juurikaan suomea tai ruotsia täsmällisempi, sen kiistaton dentaaliaffrikaatta kirjoitettiin tuolloin jokseenkin yksinomaan joko $z$ :lla tai $t z$ :lla (Reichmann-Wegera 1993, 130-133).

Vaikka Itkosen ajoitus on epäilemättä liioitellun varhainen, ${ }^{*} c c>{ }^{*} \vartheta \vartheta$ näyttää jo myöhäiskeskiajalla tapahtuneen laajalti. Kaikesta päätellen esimerkiksi Suur-Rautalammin hämäläisten eränkävijöiden kielessä oli $\vartheta \vartheta$, joka ennen pitkää omaksuttiin myös paikalliseen savolaismurteeseen fonologisena lainana asussa $h t$ (Häkkinen 1994). Nimittäin muutoin on vaikea selittää cht-kirjoitusasuja vuoden 1561 Savon ensimmäisessä maantarkastusluettelossa sekä $h t$-ääntämystä noin 1580-1630 Savosta ja Keski-Suomesta KeskiSkandinaviaan emigroituneiden metsäsuomalaisten kielessä (Rapola 1961, 42).

Jo vanhastaan on katsottu myös keskiaikaisen asiakirjaevidenssin tukevan ajatusta, että $\vartheta \vartheta$ esiintyi tällöin laajalti länsisuomessa (Ojansuu 1926, 51-53; Rapola 1966, 188; Itkonen $1981,15-17)$. On silti ennenaikaista ajoittaa ${ }^{*} c c>{ }^{\star} \vartheta 9$ noin vuosiin $1200-1340$ pelkästään 1340 taltioidun sääksmäkeläisen paikannimen Laynamosse 'Lainametsä' vuoksi (Heikkilä 2016, 148, 152). Yksittäisen kirjoitusasun todistusvoimaa ei näet muutenkaan saisi yliarvioida ja vähiten tällaisessa tapauksessa, jossa nimi oli saattanut kulkeutua useammankin vieraskielisen välikäden kautta ennen päätymistään kaukana Avignonissa vaikuttaneen paavi Benedictus XII:n pannabullaan (DF 467$){ }^{6}$

Kuten yllä olen jo perustellut, ${ }^{*} c c>{ }^{*} \vartheta 9$ ei ole äänteenmuutos, jonka absoluuttinen ajoittaminen olisi pelkkä muutaman rivin ilmoitusasia ilman yhtä ainutta viittausta aikaisempaan tutkimukseen. Sama pätee myös muihin länsisuomen varhaisimpiin fonologisiin innovaatioihin, jotka ovat poikkeuksetta ajalta, jolloin kirjallisia muistomerkkejä oli joko vähän tai ei ollenkaan. Ensimmäisenä on usein pidetty diftongiutumista ${ }^{\star} o o>{ }^{\star} u o$, ${ }^{*} \ddot{o} 0 \ddot{>}>{ }^{*} \ddot{u} \ddot{o},{ }^{*} e e>{ }^{*} i e$, sillä se levisi länsisuomesta varhain mutta silti vasta muinaiskarjalan hajottua savon kautta varsinaiskarjalaan (Sammallahti 1977, 128). ${ }^{7}$

6 Samassa pannabullassa peräti kolmesti mainittu Vendentaka 'Vedentaka' ei sekään todista mistään prenasalisaatiosta vaan itsestään selvästi ainoastaan paavin kirjurin suomentaidottomuudesta.

7 Etenkin Heikki Leskinen $(1964,101-104)$ on perustellut diftongiutumisen muinaiskarjalaisuutta lähinnä sillä, etteivät lingvistiset innovaatiot olisi muka voineet ylittää Pähkinäsaaren rauhan rajaa, joka todellisuudessa kuitenkin oli kaikkea muuta kuin rautaesiripun kaltainen este (ks. Korpela 2006). 
Näin ollen todistukseksi länsisuomenkin varhaisesta diftongiutumisesta on katsottu 1200luvun puolivälissä kirjoitetun Novgorodin tuohikirjeen 292 karjalaisena pidetty нуоли 'nuoli' (Krook 1999, 22-24). Vaikka heti seuraavalta riviltä löytyvätkin ноули ја ноли, johtopäätös olisi ollut täysin uskottava, ellei 〈yo〉 (samoin kuin 〈oy〉) olisi ollut Novgorodin slaavissa monoftongin /u/ grafeemi (Vermeer 1991, 318-319). Lukuasun taustalla voisi täten yhtä hyvin olla geneerinen itämerensuomalainen *nooli (Laakso 1999, 533-534), joskin on kiintoisa sattuma, että eräissä Novgorodia maantieteellisesti lähimmissä itämerensuomalaisissa kielissä ${ }^{*} o o,{ }^{*} \ddot{o} 0 ̈$ ja ${ }^{*} e e$ ovat sittemmin supistuneet (vrt. ink. nōli, viE nuúl).

Sitä vastoin huomattavasti vähemmän uskottava on ajatus, että vuodet 741-829 kattavan kronikan Annales regni Francorum vuoden 811 kohdalla mainitsemalla tanskalaisella henkilönnimellä Suomi (po. Gluomi?) olisi jotain tekemistä maannimen Suomi kanssa (Pekkanen 1963) - saati sitten että se todistaisi diftongiutumisen ${ }^{*}$ oo $>{ }^{*} u o$ tapahtuneen länsisuomessa noin 650-750 (Heikkilä 2016, 147). Ainoana lisätodisteena mainittu itämerensuomalainen lainaetymologia ruotsin etnonyymille ryss 'venäläinen' (Heikkilä 2014, 189) on sekin fonologisista, kronologisista ja semanttisista syistä hylättävä (Schalin 2014, 428-429). Ehkä ${ }^{\star} o o>{ }^{\star} u o$ samoin kuin ${ }^{\star} o \ddot{o}>{ }^{\star} \ddot{u ̈ o ̈ ~ j a ~}{ }^{\star} e e>{ }^{\star} i e$ ajoittuvat jo ensimmäiselle vuosituhannelle, mutta sitä ei silti todisteta ihan näin heppoisin perustein.

\section{Keskiajan suomi}

Taulukko 2. Keskiajan suomen foneemit

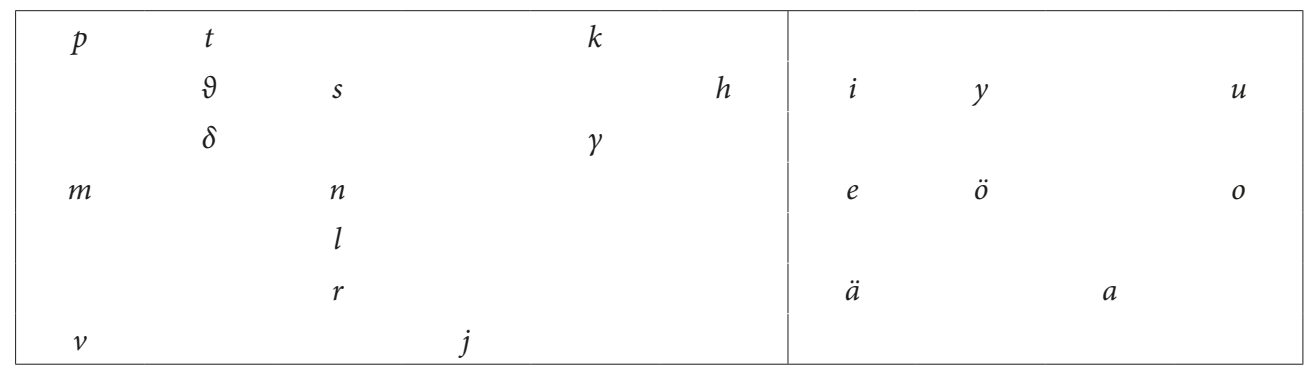

Varhaissuomalaisten äännekehitysten seurauksena keskiajan suomen vokaaliparadigma oli säilynyt ennallaan, kun taas konsonanttiparadigma oli hieman kasvanut (ks. taulukko 2). Tämä johtui ennen muuta astevaihtelun fonemaattistumisesta ja morfologistumisesta, jotka taas aiheutuivat kehityksistä ${ }^{\star} \beta>{ }^{*} v$ sekä ${ }^{*} p \breve{p}>{ }^{*} p,{ }^{*} t \breve{t}>{ }^{*} t,{ }^{\star} k \breve{k}>{ }^{*} k$. Keskiajan suomen foneemiparadigma säilyi puolestaan lähes sellaisenaan vanhaan kirjasuomeen, jossa ainoa mahdollinen uusi tulokas oli /n/ (Posti 1951, 413-415; Rapola 1966, 86-88). ${ }^{8}$

8 Kokonaan oma lukunsa olivat kirjakielessä vierassanoissa esiintyneet $b, d, g$ ja $f$, jotka eivät vielä näyttäisi kuuluneen puhekieleen, sillä ainakin Anders Bure kirjoitti vuonna 1626 suomalaisten ääntämisestä seuraavasti: "Kun pitäisi sanoa bonus, he sanovat ponus, dominus ääntyy tominus, guberno 
Keskiajan alku merkitsi koko itämerensuomalaisella kielialueella murrosta, kun itäiset kantamurteet joutuivat Novgorodin siinä missä eteläiset Saksalaisen ritarikunnan vallan alle. Länsisuomalainen kantamurre joutui taas Ruotsin vallan alle viimeistään niin sanotun Hämeen ristiretken seurauksena 1249 (Jokipii 2000). Pähkinäsaaren rauhassa v. 1323 länsisuomi sai vielä seuraa muinaiskarjalaisista savon ja viipurinkarjalan murteista, jos kohta kumpikin oli pitkään länsisuomen suhteen pikemmin ottavana kuin antavana osapuolena (Leskinen 1964). ${ }^{9}$

Jo varhaissuomen aikaisissa 1000-luvun ruotsalaisissa riimukivissä erotettiin käsitteet 'Suomi' (dat. fin·lonti; SRI U 582) ja 'Häme' (dat. tafstalonti; SRI Gs 13). Kyse ei silti välttämättä ollut lounais- ja hämäläismurteiden jyrkästä murre-erosta vaan siitä, että Varsinais-Suomi ja Häme olivat olleet jo keski- ja myöhäisrautakaudella toisistaan alueellisesti eronneita kokonaisuuksia. Kielellisten erojen sijasta saattoi hyvin esiintyä muita etnisiä eroja, sillä hämäläiset (= saN sápmelaččat 'saamelaiset') säilyttivät heimonnimessäänkin muiston aiemmasta saamelaissubstraatistaan (Salo 2000).

Tosin lounaismurteet on hiljattain haluttu korottaa peräti yhdeksi suomen päämurteistoksi johtuen niiden monista merkittävistä muualta puuttuvista innovaatioista (Paunonen 2006). Jotta evidenssillä olisi silti klassifikatorista merkitystä, tulisi pikemmin esittää kaikille muille paitsi lounaismurteille yhteisiä innovaatioita. Toisaalta vaikka lounaismurteiden virolaisuuksia on aikaisemmin ajoitettu jo ensimmäisen vuosituhannen puolelle (Itkonen 1972, 105-106; 1983, 201-202), piirteet ajoittuvat todellisuudessa virossa itsessäänkin vasta keskiaikaisiksi (Lehtinen 2007, 249-252).

Ylipäänsä voidaan syystä kysyä, ovatko nimenomaiset loppu- ja sisäheitto sekä jälkitavujen pitkien vokaalien lyheneminen sellaisia piirteitä, jotka olisi välttämätöntä selittää vieraalla vaikutuksella. Alkupainoisten kielten kohdalla on näet huomattavasti harvinaisempaa painottomien jälkitavujen säilyminen sellaisinaan, kuten etäsukukieltemme äännehistoriasta havainnollisesti näemme. Myös lähisukukielistämme vepsä on kokenut painottomien jälkitavujen heikkenemistä jopa samanlaisin edellytyksin kuin viro ja suomen lounaismurteet (Leskinen 1990, 72-76).

Joka tapauksessa jo alan pioneeri Ojansuu (1901, 155-198) päätteli keskiaikaisissa asiakirjoissa mainittujen paikannimien perusteella lounaismurteiden "loppuheiton olleen pitkälle kehittyneen 1300:n tienoilla". Niin huolellista kuin hänen argumentaationsa olikin, itse ajoitus silti pohjautui paljolti varhaisimpiin positiivisiin indiiseihin loppuheitosta. Samaan aikaan edelleen säilyneisiin loppuvokaaleihin hän ei siis ollut kiinnittänyt riittävästi huomiotaan, kuten aiheellisesti muistutti asiasta Osmo Nikkilä (1980, 83-86; 1994, 66-73).

- cuperno, filius - wilius" (lat. pro Bonus dicunt Ponus, pro Dominus Tominus, pro Guberno Cuperno, pro Filius Wilius; Pekkanen 1985, 62, 68).

9 Tästä(kin) syystä tuntuisi varsin epätodennäköiseltä, että vanhan kirjasuomen $t z$ ja $d z$ olisivat edes osittain juontuneet kaakkoissuomalaisesta affrikaatallisesta ääntämyksestä (Rapola 1966, 186). Ylipäänsä hypoteesin elinehtona on se, että * $c c>{ }^{*} s s$ ei vielä olisi tapahtunut Viipurin seudulla, sillä Agricola tuskin olisi perustanut koko kirjasuomen ortografiaa pelkän äyrämöismurteen varaan - saati sitten tällöin yhä Venäjän puolella puhutun käkisalmenkarjalan varaan. 
Nikkilän oma ajoitus perustuikin mahdollisimman laajaan muotoryhmittäin eriteltyyn dataan. Hänen mukaansa esimerkiksi "elatiivissa loppuheittoa on 1300-luvulta 1400-luvun puoliväliin saakka satunnaisesti, mutta 1400-luvun puolivälissä loppuheittomuodot yleistyvät nopeasti eikä vuosisadan lopulla loppuvokaalisia muotoja elatiivista oikeastaan enää tavoitakaan" (Nikkilä 1980, 84) ${ }^{10}$ Ikävää, että hän ei ikinä ehtinyt ajoittaa enempää keskiajan suomen äänteenmuutoksia, sillä hänen ajoitusmetodinsa olivat kerta kaikkiaan esikuvallisia.

Samaa ei valitettavasti voi sanoa Mikko Heikkilän ajoituksista. Hänen mukaansa "useimmat suomen murteiden tutkimuksessa todennetut fonologiset piirteet periytyvät keskiajalta" (Heikkilä 2016, 154), jos kohta tällaisia piirteitä hän mainitsee vain kolmisenkymmentä (vrt. Rapola 1961; 1966). Toisaalta kuten jo edellä huomasimme kehitysten ${ }^{*} c c$ $>{ }^{*} \vartheta 9$ ja ${ }^{*}$ oo $>{ }^{*}$ uo kohdalla, Heikkilälle riittää kunkin äänteenmuutoksen tapahtumisesta todisteeksi vähäisempikin positiivinen indiisi, kun taas vastaesimerkkejä hän ei juuri mainitse saati selitä.

Esimerkeikseni valikoituivat hämäläismurteiden $\delta>l$ sekä lounais- ja pohjalaismurteiden $\delta>r$, joita Heikkilä ainoina äänteenmuutoksina käsittelee useammassa kuin yhdessä kappaleessa ja joita myös itse olen käsitellyt hiljattain (Kallio 2013). Koska aina 1700-luvulle saakka kaikki muut $\delta$ :n kirjoitusasut kuin $d$ ja $d h$ olivat jokseenkin olemattomia, päädyin kannattamaan perinteistä ajoitusta, että $\delta>l$ ja $\delta>r$ käynnistyivät vasta uudella ajalla. Muutenkin teoreettinen lähtökohtani oli (ja on) se, että kirjallisuuden ja asiakirjojen normaaliedustus täytyisi aina katsoa todistusvoimaisemmaksi kuin kourallinen satunnaisia poikkeusedustuksia.

Heikkilän teoreettinen lähtökohta on täysin päinvastainen painotuksen ollessa yksittäistapauksissa. Ensinnäkin $\delta>l$ tapahtui hänen mukaansa noin 1350-1420. Väitteen hän perustaa Köyliöstä 1420 attestoiduihin nimiin Kolisoya ja Kolisoianma (Heikkilä 2016, 139-143, 153). Häntä ei lainkaan häiritse se, että $\delta$ säilyi Köyliössä aina 190o-luvun alkuun (Ojansuu 1903, 34), ja vasta sen jälkeen sotien välisenä aikana seudulla tapahtui $\delta>\partial^{11}>r$ (Virtaranta 1958, 135-136). Tällaiset vesistöihin liittyvät Kolis-nimet eivät kaikesta päätellen kuulukaan Kodis- vaan Koliseva-nimien yhteyteen (Kiviniemi 1971, 85-89, 187-193).

Muut Heikkilän esittämät varhaisimmat $l$-attestaatiot koskevat konsonantin etistä asemaa, jossa $\delta>l$ olikin aiempi. Tosin hänen mielestään "ei ole riittäviä perusteita pitää äänteenmuutoksia $\delta C>l C$ ja $\delta V>l V$ erillisinä eikä eriaikaisina, sillä molemmista on todisteita samalta ajalta" (Heikkilä 2016, 152). ${ }^{12}$ Silti niin kauan kuin todisteet jälkimmäisestä ovat

10 Niin yksipuolinen kuin keskiajan suomen korpus olikin yleisesti ottaen, moni paikannimi silti tavattiin elatiivissa tai ablatiivissa (vrt. Vanajassa 1385 Olaff Rochoylasta, Benct Twrcahawolta; DF 929). Kuten Oliver Blomqvist (2015) on todennut, keskiaikaisten kirjureiden mainettaan parempaan suomen taitoon viittaisi se, että ruotsin prepositio ja suomen erosijapääte esiintyivät erittäin harvoin rinnakkain (vrt. Turussa 1378 Philippus aff Koskelta; DF 871), minkä voi myös todeta Nikkilän (1980, 93-97) julkaisemasta aineistosta.

11 Huom. SUT $\delta=$ IPA $\partial$, mutta SUT $\partial=$ IPA $r$ (ts. yksitäryinen tremulantti).

12 Tarkalleen ottaen ei edes ollut mitään yleistä ja yhtäläistä kehitystä $\delta C>l C$, vaan $\delta$ kehittyi ainoastaan puolivokaalien edellä likvidaksi, kun taas muutoin tavataan $\delta m>V m, \delta n>n n$ sekä $\delta r>V r$ paitsi Kaakkois- ja Päijät-Hämeessä $\delta r>r r$ (Rapola 1966, 196-233). Heikkilä $(2016,148-149)$ esittää vakiintuneille äännelaeille kaksi vastaesimerkkiä, vaikka ei juuri erittelekään omia äännelakejaan. En- 
lähinnä yllä mainitun kaltaisia väärin etymologisoituja yksittäistapauksia, en näe syytä tarkistaa kantaani - erityisesti koska Heikkilä ei selitä sitä, miksi $\delta>l$ rajoittui vokaalin edellä vain Hämeeseen, kun taas esimerkiksi v:n edellä se ulottui Suomenlahdelta aina Jäämerelle (ks. esim. Kettunen 1940, kartat 27, 65-66).

Silloinkin kun asiakirjojen nimiaines on etymologisoitu oikein, kannattaa muistaa Pertti Virtarannan $(1958,213)$ sanat: "Esim. Rauman seudun heikosti spiranttihälyinen $\delta$ on niin kaksihahmotteinen äänne, että sen on joskus kuulevinaan aivan l:nä”. Jos ja kun jopa tulevalle fennistiikan akateemikolle tuotti vaikeuksia erottaa $\delta$ ja $l$ toisistaan, sama koski sitä suuremmalla syyllä Ruotsin vallan aikaisia kirjureita riippumatta heidän äidinkielestään. Myöhemmältä $r$-alueelta Nousiaisista 1540 attestoitu Valawaijniå 'Vadanvainio’ (mt., 143) selittyykin sillä, että kuulemastaan epävarmalle mutta silti suomentaitoiselle kirjurille vala oli epäilemättä tutumpi sana kuin vata.

Heikkilän $(2016,143-145,153)$ mukaan $\delta>r$ tapahtui puolestaan noin 1420-1448, minkä hän perustaa Piikkiöstä 1448 taltioituun nimeen Hirisundh 'Hiirsalmi'. Vaikka määriteosan on aiemminkin arveltu olleen hiisi (murt. gen. hiiden > hiiren) eikä hiiri (Huldén 2001, 161), identifikaatiota on silti syytä epäillä, sillä Hiiri-nimiä esiintyy runsaasti ympäri maata riippumatta siitä, oliko $\delta>r$ tapahtunut lähimaillakaan. Jos ja kun sivuutamme jälleen kaikki $\delta C$-sanat, myös muut hänen luettelemansa varhaisimmat $r$-esiintymät ovat Hiiri-nimien kaltaisia kyseenalaisesti $\delta$ :llisiksi etymologisoituja yksittäistapauksia.

l-esiintymien tavoin myös $r$-esiintymien levikki on Heikkilällä jokseenkin mielivaltainen; toki ne toisinaan sijaitsevat myöhemmällä $r$-alueella, ${ }^{13}$ mutta vielä useammin ne sijaitsevat jossain ihan muualla. ${ }^{14}$ Hän joutuukin turvautumaan ad hoc -oletukseen, että

simmäinen on Kiikasta 1478 alkaen taltioitu Gudmundila 'Kulmuntila', jonka kantaosa selittyy parhaiten kehityksen $\delta m>V m$ jälkeisenä lainana muinaisruotsalaisesta henkilönnimestä Gudhmunder. Toinen puolestaan on Harjavallasta 1442 alkaen taltioitu Hawala 'Hauvola', jonka kymmenien eri esiintymien joukosta löytyvät kahdesti 1445 ja $1481 d w$ sekä kerran $1473 r w$ mutta muuten $u v$ :hen viittaavat $w, u, u f w, f f w, f f u, w f f u, u f f u$ jne. (Suvanto 2001, 1468-1470). Historiallisessa kielitieteessä äännelait on kuitenkin tapana perustaa perussanastoon eikä suinkaan henkilönnimipohjaiseen asutusnimistöön.

13 Osittain koska Ruotsissakin on järvi nimeltään Röringen (Hellquist 1903-1906, 514), Vetelistä 1547 alkaen attestoitu Röringe 'Räyrinki' on aiemmin lähes yksimielisesti tulkittu ruotsalaisperäiseksi (esim. Saxén 1905, 256; Karsten 1921, 172-174; Räisänen 2003, 25). Hiljattain nimi on silti selitetty johdokseksi verbistä ryötyä 'ryvettyä, likaantua, joka on kuitenkin niin harvinainen ja myöhäinen variantti synonyymistään ryöttyä (< ryvöttyä < ryvettyä), että sen olemassaoloa yksinäis-t:llisenä jo 1500-luvun alkupuolella on vahvat syyt epäillä - etenkin kun selitykseen edelleen yhdistyy oletus epäsäännöllisestä kehityksestä $y \ddot{a}>\ddot{a} y$, jonka taas olisi aiheuttanut ihan toinen verbi räytyä 'riutua, surkastua, ränsistyä' (ts. Ryöringi 1799 > Räyrinki 1875; SPK s.v. Räyrinki; Heikkilä 2016, 143).

14 Vaikka Kangasala kuuluu perinteiseen $l$-alueeseen (Virtaranta 1958, 80), Heikkilän $(2016,144)$ mielestä $\delta>r$ tapahtui sielläkin todisteenaan ensimmäisen kerran 1510 attestoitu Rarunsalo 'Raronsalo', jonka määriteosan hän yhdistää sanaan rata. Silti samaisessa kihlakunnantuomari Jaakko Folmerinpojan tuomiokirjeessä (DF 5462) mainittiin myös kehitykseltä $\delta>r$ välttyneet Sudhenhauta 'Sudenhauta' sekä Ruohaudhan makey'Rutahaudanmäki' (Suvanto 2001, 795-796), jotka panevat jo vahvasti epäilemään identifikaatiota, ja lopullisen kuoliniskun sille antaa Kangasalla 1427 lautamiehenä mainittu Olaff Raro (DF 1849), joka siis itse tai joku hänen sukulaisensa oli todennäköisimmin nimen Raronsalo takana. 
keskiajan ja uuden ajan taitteessa esiintyivät rinnakkain eliitin suosima $\delta$, eränkävijöiden suosima $l$ sekä sotilaiden suosima $r$ (Heikkilä 2016, 146). Heti perään hän silti väittää, että kirjureilla $d$ ja $d h$ olivat "Turun murteen äänneasussa" siinä missä $l$ ja $r$ "paikallisen murteen mukaisessa äänneasussa" (mt., 146-147), vaikka todellisuudessa juuri Turun murteessa $\delta>r$ tapahtui jo ensimmäisten joukossa (Virtaranta 1958, 213-216).

Edelleen Heikkilän (2016, 151-152) mielestä keskiaikainen oikeinkirjoitus veti vertoja Agricolan aikaiselle, mitä hän perustelee ainoastaan neljällä esimerkkisanalla. ${ }^{15} \mathrm{Ei}$ tarvitse silti käydä läpi kuin Ojansuun (1926) keräämä aineisto, että päätyy päinvastaiseen johtopäätökseen. Vaikka horjuvalla ortografialla ei ollut suoraa tekemistä kirjurin äidinkielen kanssa, keskiajan samoin kuin uuden ajan kirjureihin kuului todistetusti myös riikinruotsalaisia, jotka eivät osanneet suomea Turun murteesta puhumattakaan, vaan he kirjasivat ylös vain sen, minkä olivat omin korvin kuulleet (Palomäki 1998, 254-257).

Yhteenvetona todettakoon, ettei Heikkilä kykene esittämään uusia painavia argumentteja kehitysten $\delta>l$ ja $\delta>r$ varhaisuuden puolesta. Vieläkin raskauttavampaa on silti se, että hän ei juuri käsittele niiden varhaisuutta vastaan esitettyjä argumentteja (joista tarkemmin Kallio 2013). Ennen kaikkea hän jättää vastaamatta siihen, kuinka ihmeessä suomea taitamattomat Ruotsin vallan aikaiset kirjurit olisivat tienneet, milloin heidän kuulemiensa l:n ja $r$ :n taustalla oli aiempi $\delta$ - varsinkaan kun edes suomea taitavat nykylingvistit eivät aina näyttäisi tietävän, milloin heidän asiakirjoista löytämiensä $l: n$ ja $r: n$ taustalla oli aiempi $\delta$.

Vielä vähemmän suomea tunsi anonyymi saksalainen, joka ilmeisesti 1428-1449 kävi taltioimassa Nürnbergissä käsikirjoituksena säilyneeseen matkakertomukseensa seuraavan sitaatin tuolloiselta Turun piispalta (jota hän ei maininnut nimeltä mutta joka 14121450 oli sukunimestään huolimatta Mynämäessä syntynyt Maunu II Tavast): Mÿnna thachton gernast spuho somen gelen Emÿna dä̈da (Wulf 1982). Tallentajan yläsaksalainen äidinkieli selittää jopa keskiajan suomen mittapuulla varsin kaoottisen oikeinkirjoituksen (Winkler 1998, 23-25). Agricola olisikin kirjoittanut saman selvästi ymmärrettävämmin: Mine tadhon kernast puhua Somen kielen / Em mine taidha (IA). ${ }^{16}$

Todellinen 1400-luvun alkupuolen ääntämys lienee kuitenkin ollut yllättävän lähellä

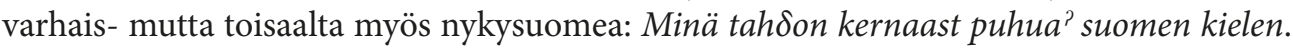

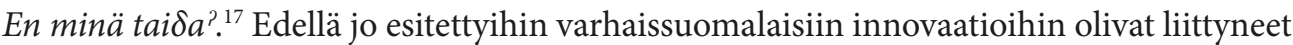

15 Myös Agricolan tuotannosta voi halutessaan löytää kokonaisia raamatunjakeita, joiden oikeinkirjoitus on moitteeton jopa nykymittapuulla. Esimerkiksi hänen rukouskirjansa sisältää seuraavan jakeen (1544): Alghusa oli Sana / Ja Sana oli Jumalan tykenä / Ja Jumala oli se Sana (Joh. 1:1). Ainoat erot vuoden 1938 raamatunkäännökseen ovat fonologisia eivätkä siis varsinaisesti ortografisia (ts. alyusa, tykenä alussa, tykönä).

16 Lauseita ei luonnollisestikaan tällaisinaan Agricolalta tavata, mutta jokainen yksittäinen sana tavataan jopa täsmälleen samoine taivutusmuotoineen. Eri kirjoitusasuista olen aina valinnut hänen normaaliedustuksensa lukuun ottamatta sanaa kernaasti, josta olen tarkoituksella valinnut samanlaisen loppuheittoisen asun kuin Nürnbergin sitaatissa.

17 Nykysuomesta poiketen keskiajan suomessa ensimmäinen lause ei sisältänyt objektivirhettä (Itkonen 1984; Häkkinen 1999, 272). 
myös painottoman tavun jälkeiset ${ }^{*} \delta>\varnothing$ ja ${ }^{\star} h>\varnothing$, sananloppuinen ${ }^{*}-k>{ }^{*_{-}}$? sekä tiettyjä muotoryhmiä koskenut loppuheitto, joista etenkin viime mainittu viittaa lounaismurteisiin (Nikkilä 1980; 1994). Silmiinpistävää kyllä vanha kirjasuomi oli osittain jopa konservatiivisemmalla kannalla, sillä esimerkiksi Agricolalta tavataan asun kernast ohella myös kernasti, kernasta ja jopa kernahasta (VKS s.v. kernaa|sti, -sta).

Agricola itse totesikin Uuden testamenttinsa esipuheessa (1548), että vaikka siinä on Somenkieli enimiten prucattu, mukana ouat mös mwiden kielet / puhet ia sanat (huom. S[u]omi 'Varsinais-Suomi', kieli 'murre'). Hänen itäsuomalaisuutensa olivat kuitenkin lähinnä leksikaalisia, kun taas fonologiassa hän näyttää pyrkineen geneeriseen länsisuomeen vältellen aikalaistensa ja seuraajiensa spesifisimpiä lounaissuomalaisuuksia, kuten erikoisgeminaatiota ja diftongireduktiota (Rapola 1962, 38-40). Lounaismurteet olivatkin sikäli ongelmallisia kirjasuomen pohjaksi, että muut suomalaiset kokivat läheisemmäksi melkein minkä tahansa vähemmän innovatiivisen murteen.

Yhtä kaikki vanha kirjasuomi ei ikinä ollut monoliitti, vaan etenkin Ljungo Tuomaanpoika 1600-luvun alun lainsuomennoksissaan Ruodzin waldakunnan Maan elj taloin poicain laki ja Kaupungin lakj Ruodzin Waldacunnasa (Ulkuniemi 1975) viljeli innolla omia pohjalaisuuksiaan. Arkaismeista mainittakoon painottoman tavun jälkeinen yksinäis- $h$ (esim. lambahan 'lampaan'), innovaatioista taas sananloppuinen ${ }^{*}-k>{ }^{*}-t$ (esim. estet 'este'). Pohjalaismurteiden varhaisin muistomerkki lienee silti ilmeisesti jo 1540-luvun alussa kirjoitettu Kangasalan messu, vaikka sen takana olleen Lauri Heikinpojan syntyperästä ei olekaan täyttä varmuutta (vrt. Häkkinen-Tuppurainen 2014).

Hämäläismurteiden vanhin muistomerkki lienee puolestaan Kustaa Vaasan Helsingissä 21.11.1555 allekirjoittaman kirjeen suomennos. ${ }^{18}$ Vaikka kääntäjän henkilöllisyydestä ei ole tietoa, hän saattoi hyvin olla aivan Helsingin lähinaapurista etelähämäläiseltä Keski-Uudeltamaalta, jonne viittaavat useimmat hänen murrepiirteistään (esim. pronominit mee, tee, hee ja see, persoonapäätteet -mme ja -tte sekä possessiivisuffiksit -mme ja -nne; Nikkilä 1994, 36-37). Toisaalta kirjeestä jälleen tavataan sittemmin melkein koko Hämeestä väistyneenä arkaismina painottoman tavun jälkeinen yksinäis-h (esim. Makundahan 'maakuntaan', tarwitahan 'tarvitaan').

Vaikka vanhasta kirjallisuudesta löytyy siis tavan takaa murteellisuuksia, kehityksistä $\delta>l$ ja $\delta>r$ ei silti tavata jälkeäkään, ja sama pätee myös kehityksiin $\vartheta \vartheta>t t$ ja $\vartheta \vartheta>s s .{ }^{19}$ Koska vielä 1800- ja 1900-luvulla $\vartheta \vartheta$ ja $\delta$ väistyivät käsi kädessä (Streng 1907; Virtaranta 1958), voimme hyvin olettaa samanlaista tapahtuneen jo $1600-$ ja 1700 -luvuilla. Vaikka $\vartheta \vartheta: n$ ja $\delta: n$ jatkajia on nyttemmin pidetty länsimurteiden keskeisimpinä tuntomerkkeinä,

18 Vakava haastaja on tosin Sebastian Münsterin teoksessa Cosmographia painettu suomenkielinen Isä meidän -rukous (1544), jota on vasta aivan äskettäin vakuuttavasti esitetty kaakkoishämäläiseksi (Uusitalo 2015, 55; 2016, 167-168) ja jota olen myös itse lyhyesti käsitellyt toisaalla (Kallio 2017).

19 Tarkoitan tässä ainoastaan länsimurteiden ss-saarekkeita Uudellamaalla ja Keski-Pohjanmaalla, kun taas itämurteissa Viipurista Mikkeliin ulottuneella vyöhykkeellä muinaiskarjalainen * ${ }^{\star} c$ kehittyi suoraan ss:ksi. Mahdollisesti ss-vyöhyke oli Savossa laajempikin ennen $h t$ :n voittokulkua (vrt. Streng 1907; Häkkinen 1994). 
Agricolan aikana ei siis vielä ollut näin. Muutenkin fonologisesti länsimurteet olivat tällöin yhtenäisempiä, kun taas länsi- ja itämurteiden kieliraja oli jyrkempi, sillä niiden nykyiset siirtymämurteet olivat vasta tuloillaan (ks. esim. Savijärvi 1995).

Agricola tosin mainitsi Uuden testamenttinsa esipuheessa (1548) suomalaisten moninaiset Kielet eli puhen tauat, millä hän lienee kuitenkin viitannut pikemmin leksikaalisiin eroihin, jotka ovatkin aina keskinäisen ymmärrettävyyden kannalta häiritsevämpiä kuin fonologiset erot. Nykysuomalaisetkin ymmärtäisivät mitä tahansa itämerensuomalaista kieltä ehkä liiviä lukuun ottamatta, jos niiden erot olisivat pelkästään fonologisia. Agricola ei täsmentänyt murrejakoaan muutoin kuin luettelemalla ainoastaan tuolloiset maakunnat lukuun ottamatta ruotsinkielistä Ahvenanmaata: Some, Satacundia, Hemen maa, Carelia, Wsimaa, Rasburi ja Ite Pohiama.

Sittemmin kuitenkin Ljungo Tuomaanpoika maalainsuomennoksensa ruotsinkielisessä esipuheessa vahvisti lähes täsmälleen saman murrejaon: Nårfinland, Österbåtnen, Nyland, Wyborg, Sawoland ja Tauestland (Ulkuniemi 1975, 9). Merkillistä kyllä lounais- ja pohjalaismurteet olivat hänestä den klareste och reneste finska siinä missä Uudenmaan murre taas med svensko beblandad. Nimittäin nyttemmin juuri lounaismurteita on pidetty ruotsalaistuneina (Wiik 1992, 101-102; Lehtinen 2007, 248-252), kun taas Uudenmaan suomalaismurteet eivät edes muodosta omaa murreryhmäänsä saati erityisen ruotsalaistunutta sellaista (Itkonen 1993).

Koska Uudenmaan sittemmin kokonaan ruotsalaistunut rannikkovyöhyke oli aiemmin selvästi ollut suomenkielinen (Pitkänen 2001), tulee mieleen, olisiko kielenvaihto suomesta ruotsiin ollut kesken vielä uuden ajan alussa. Toisin sanoen Ljungon Uudenmaan suomea olisivatkin puhuneet viimeiset kaksikieliset rannikkoasukkaat mukaan luettuna pernajalainen Agricola, jonka svetisismit saisivat näin luontevan selityksen (vrt. Ikola 1988). Viime mainitun äidinkieltä koskeva loputon debatti on muutenkin malliesimerkki nationalistista diskurssia hallinneista yksikielisistä yhteisöistä jyrkkine kielirajoineen - ikään kuin suomen- ja ruotsinkielisyys sulkisivat toisensa pois.

Joka tapauksessa Ljungo tiesi aivan oikein kaakkois- ja savolaismurteiden olevan med Carelsko Ryslandz finsko förmängt (Leskinen 1964). Toisaalta kun hän totesi hämäläismurteiden olevan af allahanda finsko saman hemtat, hän lausui tavallaan ääneen myös nykytutkimuksen tunnustaman hämäläismurteiden heterogeenisuuden (Rapola 1961, 116-124; Lehtinen 2007, 258-265). Lisäksi kannattaa muistaa, että tuolloiseen Hämeeseen kuului edelleen Keski-Suomi, jonka savolaismurre edusti Limingassa syntyneelle sekä Pyhäjoella, Saloisissa ja Kalajoella kirkkoherrana toimineelle Ljungolle ehkä sittenkin kaikkein tutuinta ja läheisintä "hämäläismurretta".

Ikävä kyllä Agricolan tavoin Ljungokaan ei kertonut, millaiset piirteet erottivat toisistaan tuolloisia murteita, joista meillä on näin pelkkiä aihetodisteita. Luotettavin todistusaineisto tulee tietysti vanhimmasta kirjallisuudesta, koska juoksevassa tekstissä esiintyvät appellatiivit on huomattavasti vaikeampaa etymologisoida virheellisesti kuin vanhojen asiakirjojen luettelemat yksittäiset proprit. Sitä paitsi monien kirjailijoiden kotipaikka on selvillä toisin kuin asiakirjoja rustailleiden kirjurien, joista emme voi liioin juuri ikinä olla 
varmoja, ovatko he ainoastaan kirjanneet ylös kuulemansa vai ovatko he lisäksi kääntäneet sen kotona tai koulussa oppimalleen murteelle.

Nikkilän (1980, 84) huolellisten laskelmien mukaan "ei elatiivin loppuheitossa voi osoittaa mitään paikallisia eroja", vaikka "asiakirjat koskevat paitsi Lounais-Suomen myös Satakunnan ja Hämeen seutuja". Elatiivin loppuheiton levikki on nyttemmin ulottunut lounaismurteista etelä- ja kaakkoishämäläisten murteiden kautta kaakkoismurteisiin (Nikkilä 1994, 7), mutta keskiaikainen levikki oli epäilemättä suppeampi ja olettavasti lounaiskeskeisempi. Toisaalta täytyy muistaa, että kirjureista vain pieni (suomentaitoisin?) osa viljeli erosijoja; vaikka keskiaikaisia asiakirjanimiä on säilynyt jopa tuhansia, niistä kuitenkin ainoastaan vajaat parisataa tavataan elatiivissa tai ablatiivissa (Nikkilä 1980, 93-97).

\section{Lopuksi}

Siinä missä varhaissuomalaisena aikana länsisuomi itsenäistyi omaksi itämerensuomalaiseksi kantamurteekseen, keskiajan suomi edusti ajanjaksoa, jolloin länsisuomi itse alkoi eriytyä myöhempiin päämurteisiinsa. Areaalitypologisena oppikirjaesimerkkinä ydinalueella puhutut lounaismurteet olivat innovatiivisimmat, periferiassa puhutut pohjalaismurteet taas konservatiivisimmat. Hämäläismurteita voidaan taas pitää pikemmin areaalisena kuin geneettisenä yksikkönä, sillä niitä ei oikeastaan yhdistä muu kuin se, että ne ovat lounais- ja pohjalaismurteiden ulkopuolisia länsimurteita (Kallio 2013, 270).

Kaikesta huolimatta länsisuomi säilyi läpi koko keskiajan suhteellisen yhtenäisenä. Vasta kun Kustaa Vaasa oli 1542 takavarikoinut erämaat valtiolle ja lakkauttanut erätalouden, länsisuomalaisten liikkuvuus romahti ja murre-eroja alkoi toden teolla syntyä. Silti vielä $1800-l u v u l l a k a a n$ suomella ei ollut ruotsin älvdalskan kaltaista muille puhujille lähes käsittämätöntä "murrettaan", mikä niin ikään viittaisi verraten nuoreen murrediversiteettiin. Kannattaa lisäksi muistaa, että varhaissuomea ja keskiajan suomea puhuttiin yhä varsin suppealla alueella, sillä valtaosa Suomesta oli edelleen saamenkielistä.

Länsisuomalainen kielialue laajeni keskiajalla ennen kaikkea pohjoisen suuntaan (Leiviskä 2015). Toisaalta idässä kruunu pyrki liittämään Novgorodilta valloitetun Viipurin linnaläänin kiinteämmin itseensä sijoittamalla sinne länsisuomalaisia uudisasukkaita, joiden kielellistä vaikutusta sikäläisiin muinaiskarjalaisiin murteisiin on silti liioiteltu. ${ }^{20}$ Uudelle ajalle tultaessa länsisuomalainen kielialue alkoikin idästä käsin supistua ennen muuta savolaisekspansion seurauksena, mutta sittemmin myös kaakkoismurteellisuudet

20 Esimerkiksi Leskisen luettelemat viipurinkarjalan länsisuomalaisuudet $(1964,105-106)$ ovat joko arkaismeja (esim. liudentumattomuus, $a a: n$ ja ää:n diftongiutumattomuus sekä ä:lliset kieltoverbin imperatiivit) tai muuten epäuskottavia (esim. ${ }^{*} c c$ :n kehittymistä ss:ksi ei ole tarpeellista selittää länsisuomen $9 \vartheta$ :n vaikutuksella). Sen sijaan $k l$ - ja $k r$-yhtymien alkukomponentin vokaaliutuminen oli selvä länsisuomalaisuus, joka näyttää kaiken kukkuraksi levinneen leksikaalisena diffuusiona ainakin sanakohtaisista levikkikartoista päätellen (vrt. Kettunen 1940, kartat 12-15). 
valtasivat alaa, kun Kymijoen itäpuolinen kaakkoishämäläinen murrealue joutui liitetyksi Viipuri-johtoiseen Vanhaan Suomeen 1743 (vrt. Leskinen 1964, 112-113).

Lopulta vasta $1800-l u v u n$ aikana syntyi ylhäältä ohjattuna nykysuomeksi kutsuttu länsisuomalais-muinaiskarjalainen sekakieli, jossa toki länsisuomalainen osuus on edelleen selvästi hallitseva - varsinkin kun nykysuomen muinaiskarjalaisuudet ovat usein samalla kantasuomalaisuuksia (esim. ksm./mka. ${ }^{*} c c \sim s m . t s ; \mathrm{ksm} . / \mathrm{mka} .{ }^{{ }^{*}} t v \sim \mathrm{sm} . t v$ ). Siinä missä monessa muussa maassa pääkaupungin murre otettiin jokseenkin sellaisenaan kirjakieleksi, Suomessa jouduttiin tekemään poikkeus, sillä pääkaupunki Helsinki oli ruotsinkielinen. Siihen nähden, ettei nykysuomi ollut alkuaan kenenkään kotimurre, se onkin osoittautunut suorastaan hämmästyttävän elinvoimaiseksi. ${ }^{21}$

\section{Lähteet}

Agricola, Mikael 1544: Rucouskiria / Bibliasta. Amund Lauritzenpoica, Stocholm.

1548: Se Wsi Testamenti. Amundi Lauritzan poica, Stocholm.

Aikio, Ante 2004: An Essay on Substrate Studies and the Origin of Saami. Irma Hyvärinen, Petri KAllio ja JARmo Korhonen (toim.): Etymologie, Entlehnungen und Entwicklungen: Festschrift für Jorma Koivulehto zum 7o. Geburtstag, 5-34. Mémoires de la Société Néophilologique de Helsinki 63. Société Néophilologique, Helsinki.

2014: Studies in Uralic Etymology II: Finnic Etymologies. Linguistica Uralica 50, 1-19.

Aikio, Aslak - Aikio, Ante 2001: Heimovaelluksista jatkuvuuteen: Suomalaisen väestöhistorian tutkimuksen pirstoutuminen. Muinaistutkija 4/2001, 2-21.

Bentlin, Miкко 2011: Early Finnish: A Medieval European Language. Congressus XI. Internationalis Fenno-Ugristarum VI: Dissertationes symposiorum ad linguisticam, 16-20. Reguly Társaság, Piliscsaba.

Blomevist, Oliver 2015: Naming and Multilingualism: Swedish-Finnish Personal Designations in Medieval Charters. Oliviu FelecAn (toim.): Name and Naming, 85-97. Editura Mega, Cluj-Napoca. 2016: Skriven finska före Agricola? Finska ortnamn i finländska medeltidsdiplom. Historisk Tidskrift för Finland 101, 26-51.

DF = Diplomatarium Fennicum $<$ df.narc.fi $>$. Kansallisarkisto, Helsinki.

Неıккіцё, Mıкко 2014: Bidrag till Fennoskandiens språkliga förhistoria $i$ tid och rum. Unigrafia, Helsingfors.

2016: Varhaissuomen äännehistorian kronologiasta. Sananjalka 58, 136-158.

Hellquist, Elof 1903-1906: Studier öfver de svenska sjönamnen, deras härledning ock historia. Bidrag till kännedom om de svenska landsmålen ock svenskt folkliv 20. Kungl. Boktryckeriet, Stockholm.

HuldÉN, LARS 2001: Finlandssvenska bebyggelsenamn. Skrifter utgivna av Svenska litteratursällskapet i Finland 635. Svenska litteratursällskapet i Finland, Helsingfors.

HäKKInEN, KAISA 1994: Savolainen "sohva-ilmiö"? Suomen yleiskielen ts-yhtymän murrevastineiden historiallista taustaa. Virittäjä 98, 603-609.

1999: Taidhacos somen kielen? Virittäjä 103, 269-273.

2001: Millaista oli keskiajan suomi. Congressus Nonus Internationalis Fenno-Ugristarum IV. Dissertationes sectionum: Linguistica I, 320-327. Trükk OÜ Paar, Tartu.

HäKkinen, Kaisa - Tuppurainen, Erkкi 2014: Kangasalan missalen suomenkielinen messu. Sananjalka 56, 7-28.

21 Kiitän Johan Schalinia artikkelia kirjoittaessani käymistämme lukuisista hedelmällisistä keskusteluista. 
IA = Index Agricolaensis 1980. Kotimaisten kielten tutkimuskeskuksen julkaisuja 11. Kotimaisten kielten tutkimuskeskus, Helsinki.

Iкоца, Osмо 1965: Suomen kielen kehityskaudet. Sananjalka 7, 32-40.

— 1988: Agricolan äidinkieli. Esкo Koivusalo (toim.): Mikael Agricolan kieli, 25-68. Tietolipas 112. Suomalaisen Kirjallisuuden Seura, Helsinki.

It Konen, Terho 1972: Historiantakaiset Häme ja Suomi kielentutkijan näkökulmasta. Historiallinen Aikakauskirja 70, 85-112.

1981: Zur Geschichte der ts-Verbindung in den westfinnischen Dialekten. Heikкi Leskinen (toim.): Heutige Wege der finnischen Dialektologie, 11-28. Studia Fennica 24. Suomalaisen Kirjallisuuden Seura, Helsinki.

—_ 1983: Välikatsaus suomen kielen juuriin. Virittäjä 87, 190-229, 349-386.

1984: Vanhimmat kirjatut suomen lauseet. Virittäjä 88, 467-468.

1993: Uudenmaan suomalaisasutus ja kielimaantiede. KYösti Julku (toim.): Suomen varhaishistoria, 95-121. Studia Historica Septentrionalia 21. Pohjois-Suomen Historiallinen Yhdistys, Rovaniemi.

Jokipit, MaUno 200o: Hämeen ristiretki. Jukka Peltovirta (toim.): Hämeen käräjät I, 232-279. Karisto, Hämeenlinna.

Kallio, Petri 2000: Posti's Superstrate Theory at the Threshold of a New Millennium. Johanna LaAKso (toim.): Facing Finnic: Some Challenges to Historical and Contact Linguistics, 80-99. Castrenianumin toimitteita 59. Société Finno-Ougrienne, Helsinki.

2006: Suomen kantakielten absoluuttista kronologiaa. Virittäjä 110, 2-25.

2007: Kantasuomen konsonanttihistoriaa. Jussi Ylikoski ja ANTe Aikio (toim.): Sámit, sánit, sátnehámit: Riepmočála Pekka Sammallahtii miessemánu 21. beaivve 2007, 229-249. Mémoires de la Société Finno-Ougrienne 253. Société Finno-Ougrienne, Helsinki.

2012: The Prehistoric Germanic Loanword Strata in Finnic. Riho Grünthal ja Petri Kallio (toim.): A Linguistic Map of Prehistoric Northern Europe, 225-238. Mémoires de la Société FinnoOugrienne 266. Société Finno-Ougrienne, Helsinki.

2013: Hämäläisen $l: n$ ajoituksesta. Virittäjä 117, 247-252.

2014: The Diversification of Proto-Finnic. Joonas Ahola ja Frog (toim.): Fibula, Fabula, Fact: The Viking Age in Finland, 155-168. Studia Fennica Historica 18. Suomalaisen Kirjallisuuden Seura, Helsinki.

2016: Historical Phonology from Proto-Finnic to Proto-Livonian. VAlts Ernštreits ja KARL PAJUSALU (toim.): Studies on Livonian II, 39-65. Journal of Estonian and Finno-Ugric Linguistics 7:1. University of Tartu Press, Tartu.

- 2017: Sebastian Münsterin Isä meidän -rukous. Virittäjä 121, 430-436.

2019: Muinaiskarjalan uralilainen tausta. Leena Kolehmainen, Helka Riıonheimo ja Milla UUSITUPA (toim.): Tviittivirrasta veroluetteloihin: Näkökulmia Itä-Suomen monikielisyyteen.

Karsten, T. E. 1921-1923: Svensk bygd i Österbotten nu och fordom: En namnundersökning. Skrifter utgivna av Svenska litteratursällskapet i Finland 155, 171. Svenska litteratursällskapet i Finland, Helsingfors.

Kettunen, LAUri 1940: Suomen murteet III A: Murrekartasto. Suomalaisen Kirjallisuuden Seura, Helsinki.

Kiviniemi, Eero 1971: Suomen partisiippinimistöä: Ensimmäisen partisiipin sisältävät henkilön- ja paikannimet. Suomalaisen Kirjallisuuden Seuran Toimituksia 295. Suomalaisen Kirjallisuuden Seura, Helsinki.

Koivulehto, Jorma - Vennemann, Theo 1996: Der finnische Stufenwechsel und das Vernersche Gesetz. Beiträge zur Geschichte der deutschen Sprache und Literatur 118, 163-182.

KoIvusAlo, EsKo 1984: Mikael Agricola ja suomalainen lakikieli. Sananjalka 26, 31-44.

KoRPELA, JukKa 2006: Keskiaikainen itäraja läpi itäisen Fennoskandian metsävyöhykkeen: Mikä se on! Historiallinen aikakauskirja 104, 454-469.

KROOK, KRISTINA 1999: Ensi tavun ie-, yö- ja uo-diftongien avartuminen suomen murteissa. Turun yliopiston suomalaisen ja yleisen kielitieteen laitoksen julkaisuja 62. Turun yliopisto, Turku. 
Kümmel, Martin Joachim 2007: Konsonantenwandel: Bausteine zu einer Typologie des Lautwandels und ihre Konsequenzen für die vergleichende Rekonstruktion. Reichert Verlag, Wiesbaden.

LAAKso, JoHANNA 1999: Vielä kerran itämerensuomen vanhimmista muistomerkeistä. Virittäjä 103, $531-555$.

Lehtinen, TAPANI 2005: Ymmärtäisikö nykysuomalainen muinaissuomea? Tiede 9/2005, 64.

- 2007: Kielen vuosituhannet: Suomen kielen kehitys kantauralista varhaissuomeen. Tietolipas 215. Suomalaisen Kirjallisuuden Seura, Helsinki.

Leiviskä, Matti 2015: Asutusvirrat Pohjanmaalle keskiajalta 1600-luvulle. MarkKu Mattila (toim.): Aina liikkeessä: Liikkuvainen Pohjanmaa, 8-28. Aluekeskuksen tutkimuksia 7. Siirtolaisuusinstituutti, Turku.

Leskinen, HeIKKI 1964: Suomen itämurteet keskiajan ja uuden ajan taitteessa. Virittäjä 68, 97-115.

— 1990: Vepsän, karjalan ja inkeroisen asemasta kolmen äännepiirteen valossa. SARI VAULA (toim.): Itämerensuomalaiset kielikontaktit, 72-81. Kotimaisten kielten tutkimuskeskuksen julkaisuja 61. Kotimaisten kielten tutkimuskeskus, Helsinki.

Münster, Sebastian 1544: Cosmographia. Henrichus Petri, Basel.

Nikкilë, Osmo 1980: Mikael Agricolan teosten paikallissijojen loppuheitto. Folia Fennistica \& linguistica 1. Tampereen yliopisto, Tampere.

- 1994: Loppuheitto ja vanha kirjasuomi: Suomen kielen i:n loppuheiton historiaa. Opera Fennistica \& Linguistica 8. Tampereen yliopisto, Tampere.

OjansuU, HeIkKI 1901-1903: Suomen lounaismurteiden äännehistoria. Suomi 3:19, 4:2:3. Suomalaisen Kirjallisuuden Seura, Helsinki.

1916: Millaista suomea puhuttiin keskiaikana? Heikкi OJansuv: Suomen kielen tutkimuksen työmaalta: Sarja esitelmiä I, 24-43. Gummerus, Jyväskylä.

1926: Lisiä keskiajan suomen tuntemukseen. Satakunta: Kotiseutututkimuksia VI, 37-56. WSOY, Porvoo.

PALOMÄKI, Ulla 1998: Dentaalisen affrikaatan perilliset suomen murteissa: Kielikontakteihin perustuva selitysmalli. Turun yliopiston suomalaisen ja yleisen kielitieteen laitoksen julkaisuja 59. Turun yliopisto, Turku.

Paunonen, HeikKi 2006: Lounaismurteiden asema suomen murteiden ryhmityksessä. TARU Nordlund, Timna Onikki-RantajäÄsкö ja Toni SuUtari (toim.): Kohtauspaikkana kieli: Näkökulmia persoonaan, muutoksiin ja valintoihin, 249-268. Suomalaisen Kirjallisuuden Seuran Toimituksia 1078. Suomalaisen Kirjallisuuden Seura, Helsinki.

Pekkanen, Tuomo 1963: "Suomi, vir honorabilis inter suos anno 811". Virittäjä 67, 266-270.

1985: Anders Bure: Pohjoismaiden kuvaus v. 1626. Suomalaisen Kirjallisuuden Seuran Toimituksia 427. Suomalaisen Kirjallisuuden Seura, Helsinki.

Pirinen, Kauko 1988: Suomenkielisen liturgisen kirjallisuuden synty. Esko Koivusalo (toim.): Mikael Agricolan kieli, 9-24. Tietolipas 112. Suomalaisen Kirjallisuuden Seura, Helsinki.

Pitkänen, Ritva LiIsa 2001: The Oldest Toponyms and the Origins of the Population of the Finnish South Coast. Congressus Nonus Internationalis Fenno-Ugristarum VI. Dissertationes sectionum: Linguistica III, 53-58. Trükk OÜ Paar, Tartu.

PosTI, LAURI 1951: Suomen murteiden äännehistorian kysymyksiä. Virittäjä 55, 407-416.

RAPOla, MARTTI 1933: Suomen kirjakielen historia pääpiirteittäin 1: Vanhan kirjasuomen kirjoitus- ja äänneasun kehitys. Suomalaisen Kirjallisuuden Seuran Toimituksia 197. Suomalaisen Kirjallisuuden Seura, Helsinki.

1961: Johdatus suomen murteisiin: Toinen, uudistettu painos. Tietolipas 4. Suomalaisen Kirjallisuuden Seura, Helsinki.

— 1962: Vanha kirjasuomi: Toinen, undistettu painos. Tietolipas 1. Suomalaisen Kirjallisuuden Seura, Helsinki.

- 1966: Suomen kielen äännehistorian luennot. Suomalaisen Kirjallisuuden Seuran Toimituksia 283. Suomalaisen Kirjallisuuden Seura, Helsinki.

Reichmann, Oskar - Wegera, Klaus-Peter 1993: Schreibung und Lautung. Robert P. Ebert, Oskar Reichmann, Hans-Joachim Solms ja Klaus-Peter Wegera (toim.): Frühneuhochdeutsche 
Grammatik, 13-163. Sammlung kurzer Grammatiken germanischer Dialekte A: Hauptreihe 12. De Gruyter, Berlin.

Riad, Tomas 2005: Phonological Developments from Old Nordic to Early Modern Nordic III: Swedish. The Nordic languages: An International Handbook of the History of the North Germanic Languages, 1102-1115. Handbücher zur Sprach- und Kommunikationswissenschaft 22. Walter de Gruyter, Berlin.

Rintala, Päıvi 1999: Suomen ts: Teorioiden koetinkivi. Virittäjä 103, 433-448.

RÄIsÄNEN, Alpo 2003: Nimet mieltä kiehtovat: Etymologista nimistöntutkimusta. Suomalaisen Kirjallisuuden Seuran Toimituksia 936. Suomalaisen Kirjallisuuden Seura, Helsinki.

SAARIKIVI, JANNE 2000: Kontaktilähtöinen kielenmuutos, substraatti ja substraattinimistö. Virittäjä 104, 393-415.

2004: Is There Palaeo-European Substratum Interference in Western Branches of Uralic? Journal de la Société Finno-Ougrienne 90, 187-214.

SAlminen, TAPANi 1998: Pohjoisten itämerensuomalaisten kielten luokittelun ongelmia. RiHo GrüNthal ja Johanna LaAkso (toim.): Oekeeta asijoo: Commentationes Fenno-Ugricae in honorem Seppo Suhonen sexagenarii 16.V.1998, 390-406. Mémoires de la Société Finno-Ougrienne 228. Société Finno-Ougrienne, Helsinki.

Salo, Unto 2000: Suomi ja Häme, Häme ja Satakunta. Jukka Peltovirta (toim.): Hämeen käräjät I, 18-231. Karisto, Hämeenlinna.

Sammallahti, PekKa 1977: Suomalaisten esihistorian kysymyksiä. Virittäjä 81, 119-136.

$\mathrm{SAOB}=$ Svenska Akademiens ordbok 1883-. Gleerupska Universitetsbokhandeln, Lund.

SAVIJÄRvi, IlkKa 1995: Hämäläismurteen murtuminen Päijänteen länsirannalla. MARJATTA PALANder (toim.): Murteiden matkassa: Juhlakirja Alpo Räisäsen 6o-vuotispäiväksi, 217-231. Studia Carelica Humanistica 6. Joensuun yliopisto, Joensuu.

SAXÉN, RALF 1905: Språkliga bidrag till den svenska bosättningens historia i Finland I: Egentliga Finland, Satakunta och södra Österbotten. Finska Litteratur-Sällskapet, Helsingfors.

Schalin, Johan 2014: Scandinavian-Finnish Language Contact in the Viking Age in the Light of Borrowed Names. Joonas Ahola ja Frog (toim.): Fibula, Fabula, Fact: The Viking Age in Finland, 399-436. Studia Fennica Historica 18. Suomalaisen Kirjallisuuden Seura, Helsinki.

SETÄLÄ, E. N. 1890-1891: Yhteissuomalainen äännehistoria. Suomalaisen Kirjallisuuden Seura, Helsinki.

SMS = Suomen murteiden sanakirja 1985-. Kotimaisten kielten tutkimuskeskuksen julkaisuja 36. Kotimaisten kielten tutkimuskeskus, Helsinki.

SPK = Suomalainen paikannimikirja 2007. Kotimaisten kielten tutkimuskeskuksen julkaisuja 146. Kotimaisten kielten tutkimuskeskus, Helsinki.

SRI $=$ Sveriges runinskrifter 1900-1981. Almqvist \& Wiksell, Stockholm.

Streng, Harry 1907: Konsonanttiyhtymä ts suomen kielessä. Suomi 4:5. Suomalaisen Kirjallisuuden Seura, Helsinki.

Suvanto, SEPPO 2001: Vanhan Satakunnan henkilötiedosto 1303-1571. Kansallisarkisto, Helsinki.

TirkKonen, JANi-Matti 2012: "Lopullinen totuus pohjoiseurooppalaisten alkuperästä"? Kalevi Wiik vallankumouksellisen paradigman edustajana juuret-kiistassa. Pro gradu -tutkielma. Itä-Suomen yliopisto, Joensuu.

UlKUnIEMI, MartTI 1975: Ljungo Tuomaanpojan lainsuomennokset I: Maanlain ja kaupunginlain teksti. Suomalaisen Kirjallisuuden Seuran toimituksia 319. Suomalaisen Kirjallisuuden Seura, Helsinki.

UUsitalo, HARRI 2015: Reformaatioajan suomenkielisten Isä meidän -rukousten erot. Pro gradu -tutkielma. Turun yliopisto, Turku.

2016: Reformaatioajan suomenkielisten Isä meidän -rukousten suhteet toisiinsa ja lähdeteksteihin kielellisten erojen valossa. Sananjalka 58, 159-174.

Vermeer, Willem 1991: Aspects of the Oldest Finnic Poem and Some Related Texts (Novgorod Birchbark Documents 292, 56 and 403). A. M. Barentsen, B. M. Groen ja R. Sprenger (toim.): Studies in West Slavic and Baltic Linguistics, 315-359. Studies in Slavic and General Linguistics 16. Rodopi, Amsterdam.

WIIK, KALEVI 1992: Suomen kielen ja murteiden syntykysymyksiä. HANnU Remes (toim.): Lähivertailu- 
ja 6, 85-110. Kielitieteellisiä tutkimuksia 27. Joensuun yliopisto, Joensuu.

WinkLer, Eberhard 1998: Anmerkungen zu zwei Sprachdenkmälern der ostseefinnischen Sprachen. Linguistica Uralica 34, 23-29.

Virtaranta, Pertti 1958: Pääpainollisen tavun jälkeisen soinnillisen dentaalispirantin edustus suomen murteissa. Suomalaisen Kirjallisuuden Seuran Toimituksia 252. Suomalaisen Kirjallisuuden Seura, Helsinki.

VKS = Vanhan kirjasuomen sanakirja 1985-. Kotimaisten kielten tutkimuskeskuksen julkaisuja 33. Kotimaisten kielten tutkimuskeskus, Helsinki.

WUlf, Christine 1982: Zwei finnische Sätze aus dem 15. Jahrhundert. Ural-Altaische Jahrbücher: Neue Folge 2, 90-98.

\section{Petri Kallio: On the Historical Phonology of Early and Medieval Finnish}

After the North Finnic proto-language had split up into Finnish, Karelian, and Veps approximately 700 $\mathrm{AD}$, the history of the Finnish language on its own can be periodized as follows:

1. Early Finnish ca. 700-1200.

2. Medieval Finnish ca. 1200-1540.

3. Old Literary Finnish ca. 1540-1820.

4. Early Modern Finnish ca. 1820-1870.

5. Modern Finnish ca. 1870-.

While there are no written documents from Early Finnish, Medieval Finnish is fragmentarily attested primarily through personal and place names in foreign-language manuscripts. Yet, it was not until Old Literary Finnish when the literary language emerged, as its name suggests.

The present article critically discusses what can and cannot be known about Early and Medieval Finnish historical phonology. Especially Early Finnish can mainly be reached by the comparative method, because it was essentially the proto-language of the western Finnish dialects, such as Southwestern Finnish, Tavastian, and Ostrobothnian. We should note that the eastern Finnish dialects go back to Early Karelian rather than Early Finnish, thus it will not be discussed in this study.

As far as Medieval Finnish is concerned, Finnish dialectology still plays an important role, but so does Old Literary Finnish philology. However, actual Medieval Finnish data should be handled with care because it is too greatly open to different interpretations. In general, there is no justification to regard Medieval Finnish as an unexplored gold mine, which would almost be an insult to the generations of scholars who have dealt with this topic from the $19^{\text {th }}$ century onwards.

Petri Kallio

petri.kallio@helsinki.fi

Suomalais-ugrilaiset kielet ja kulttuurit

PL 24, 00014 Helsingin yliopisto 